\title{
Educación alimentaria nutricional: desafío universidad- escuela- comunidad
}

Ortigoza, Liliana D. V.; ${ }^{1}$ Sedlacek, Natalia M.; ${ }^{2}$

Recibido: 04/10/2016

Pacheco, Jimena N. ${ }^{2}$ Dezar, Gimena V. A.; ${ }^{3}$

Aprobado: 23/11/2016

\section{Resumen}

La Educación Alimentaria Nutricional (EAN) se utilizó en esta experiencia como herramienta estratégica a fin de fortalecer vínculos entre universidad y comunidad. La EAN se propone como catalizador en seguridad y soberanía alimentaria, nutrición comunitaria e intervenciones en salud. Desde el interés conjunto de la escuela secundaria pública Nº684, la Facultad de Bioquímica y Ciencias Biológicas (FBCB), Universidad Nacional del Litoral (UNL) y el Ministerio de Desarrollo Social de Santa Fe, se desarrollaron acciones interdisciplinarias participando docentes del ciclo inicial y superior de la carrera de Licenciatura en Nutrición (LN) FBCBUNL, estudiantes avanzados de LN, directivos, docentes y alumnos de la escuela, interesados en su propia salud y el bienestar de la comunidad. El objetivo del presente artículo es dar a conocer las distintas etapas que se llevaron a cabo para la concreción y desarrollo de un Proyecto de Extensión de Interés Social con eje en EAN, como así también las valoraciones de los futuros egresados en relación al proyecto. Se generaron redes tendientes a promover la EAN por parte de alumnos, Instituciones escolares, Universidad, hacia la comunidad. El desarrollo del proyecto mencionado dio lugar a experiencias educativas contextualizadas, permitiendo así integrar la docencia con la extensión.

Palabras Claves: Educación Alimentaria Nutricional, vnculos, educación Experiencial.

\footnotetext{
${ }^{1}$ Departamento de Física, FBCB, UNL.

${ }^{2}$ Cátedra de Educación para la Salud y Economía Familiar, Licenciatura en Nutrición, FBCB, UNL.

${ }^{3}$ Cátedra de Epidemiología General y Nutricional, Licenciatura en Nutrición, FBCB, UNL.
} 


\section{Resumo}

A Educação Alimentaria Nutricional (EAN) foi utilizada nesta experiência como ferramenta estratégica, com o fim de fortalecer vínculos entre a universidade e a comunidade. La EAN entendida como catalizador em seguridade e soberania alimentaria, nutrição comunitária e intervenções em saúde. Desde o interesse conjunto da escola secundaria pública No 0684, a Facultade de Bioquímica e Ciências Biológicas (FBCB), Universidad Nacional del Litoral(UNL) e o Ministerio de Desarrollo Social de Santa Fe (Ministerio de Desenvolvimento social de Santa Fe), desenvolveram ações interdisciplinares com participação de professores da educação infantil e superior da carreira de Licenciatura em Nutriçao (LN) FBCB-UNL, estudantes avançados em LN, diretores, professores e alunos da escola, interessados em sua propia saúde e no bem-estar da comunidade. O objetivo deste artigo é apresentar as diferentes etapas que foram realizadas para a realização e desenvolvimento de um Projeto de Extensão de Interesse Social com EAN eixo, bem como avaliações de futuros licenciados em relação ao projeto. Criaram-se redes para promover a EAN por parte de alunos, instituições de ensino e Universidades; para a comunidad. O desenvolvimento do projeto mencionado deu lugar a experiências educativas contextualizadas, permitindo assim integrar o ensino com a extensão universitária.

Palavras-chave: Educação Alimentaria Nutricional, links, educação Experiencial.

\section{Summary}

Food and Nutrition Education (FNE) was used in this experience as a strategic tool in order to strengthen links between university and society. The FNE is proposed as a catalyst in food security, community nutrition and health interventions. From the joint interest of public secondary school No. 0684, the Faculty of Biochemistry and Biological Sciences (FBCB), UNL, and the Ministry of Social Development of Santa Fe, interdisciplinary actions were carried out. Participating in these actions were teachers from the initial and upper cycle of the Bachelor's degree in Nutrition (LN), FBCB-UNL, advanced students of LN, managers, teachers and students of the school, who were interested in their own health and welfare of the community. The objective of this article is to present the different stages that were carried out for the concretion and development of a Project of Extension of Social Interest with axis in FNE, as well as the evaluations of future graduates in relation to the project. Networks were developed to promote FNE by students, school institutions, university, to the community. The development of the mentioned project gave rise to contextualized educational experiences, allowing to integrate the teaching with the extension.

Keywords: Food and Nutrition Education, links, experiential Education. 